\title{
Looking at the Visual Approach on American, European, and Japanese Licensed Comics Published in Indonesia and Their Influence on Indonesian Comic Industries
}

\author{
Danendro Adi \\ New Media Program, Visual Communication Design Department, School of Design, Bina Nusantara University, \\ Jakarta, Indonesia 11480
}

\begin{abstract}
A combination of narration with still images in a sequence to form a story that is defined as Graphic Narrative, Graphic Novel, or simply called Comic has been published in Indonesia since the colonial era. Since the early period of original Indonesian-made comics in the 1930's, the golden era of Indonesian comic in 1950's to the 1970's, until the era of Japanese comics published in Indonesia that survive until now, in order to create "original" Indonesian Comic and to maintain its existence, Indonesian comic artist have been influenced by foreign-licensed comic artworks as they have been published in Indonesia. This paper will discuss how comic on each era have made impacts on local comics and the influences in coloring the pop culture in Indonesia. This study began with a brief history of comic and its existence in Indonesia and then the visual characteristics that related to its readers characteristics from each era will be discussed.
\end{abstract}

Keywords : Graphic Narrative, Indonesian Comic

\section{INTRODUCTION}

Both pictures and words, each have strengths that can be combined to become stronger media to deliver message. Some of the strength of picture such as, able to communicate quickly, suitable to a wider audience, not limited to age and location, can be enjoyed repeatedly that maight build emotion, memories and experiences, and pictures can be placed in order to produce a sequence. While words are very strong to communicate accurately, and amusing through language and sentences [1].

Graphic narrative, a term first introduced by David Kunzle in the book The History of the Comic Strip, as a form that combines the still image composition with narration to form a story [2]. Referring to these definitions, Petersen said that the terminology with a similar explanation, in French called Bande Dessinee which means image in the sequence. The definition of Graphic Narrative, Graphic Novel, or Comic Art, in another parts of the world simply called Comic, Manga, and others [3]. Similar to the Kunzle's definition, Scott McCloud, a comic expert, define it as a series of pictures in deliberate sequence [4]. In term of visual aesthetic, Comics are able to deliver story on caricature or realistic-anatomically correct-illustration style. Both visual approaches are can be found on comics that published in Indonesia and have been accepted among the readers.

The first comic in Indonesia was on the Dutch East Indies period. The existence in Indonesia was cannot be separated from the role of mass media which became the place where it was introduced to public, as explained by Marcel Bonneff that the De Java Bode (1938), the Dutch language newspaper that inserting Filippie Flink comic strip on the children's rubric. Then, the world famous adventure comic, Flash Gordon, is placed on the weekly media, De Orient. Followed by Sin Po, the Chinese-Malay newspaper that in Malay language, in 1931 introduced Put On, a humor comic strip which can be recognize as the first published comic that created by local comic artist, and the artist, Kho Wan Gie as the first generation of Indonesian comic artist [5]. Following Put On's success to meet the tastes of Chinese-Indonesian readers, Star Weekly magazine presented Sie Djin Koei, an Asian fighting themed comic that inserted together with comic strips that mostly from the Western. The comic that created by Siauw Tik Kwie was able to match the popularity of Flash Gordon and it became the pioneer of Indonesian fighting themed comic that reach the top of its popularity in the late 1960's [6].

In the mid-fifties, looking at the popularity of western comics, local comic artists tried to make superheroes characters become more Indonesian. Imitation character from American superhero comic has begun to be published. Sri Asih, a superman-like superwoman, created by R.A. Kosasih, published in 1954 can be said as the beginning of the growth of Indonesian comics. Since that time, Indonesian comic became widely known among comic the readers, as contrast comic strips on mass media become less popular. After Sri Asih, more Indonesian comics in superhero genres emerged. New local superhero were appeared in not very long period, such as Putri Bintang dan Garuda Putih (Star Princess and White Garuda), followed by Gundala, Godam, and many others in the late 60s [7].

Comics that taken from folklore and the Wayang story that taken from Ramayana and Mahabharata, have been well accepted by the reader because it is considered more educated and match with the nations culture. Since published in the early sixties, the Wayang comics have been able to shift its popularity to the Western comics, until its popularity was faded by other Indonesian comic genres, fighting, superheroes and romance comics that lasted until 1970's [8].

The downturn of Indonesian comic in the late 1980's can be said as the end of the golden era of comic with 
Indonesian original idea. Indonesian comic artists are only able to work on supplements in newspapers and magazines, as what in the early appearance of Indonesia comic. In 1975 the first comic of The Adventure of Tintin was published in Indonesia. The comic that created by famous Belgian comic artist, Georges Remi (Hergé), due to its best-selling, from 20 titles that published by Indira, some certain titles are reprinted up to eleven times. The popularity of Tintin has attracted other publishers to also published more Europeanlicensed comics title before the dominance were fade out as the rise of Manga, the Japanese comic, that published in Indonesia.

The early 1990's were as the rise of Japanese-Licensed comic In Indonesia. Akira is the first Japanese comic to be officially published in Indonesia in 1990 by Elex Media Komputindo, the publisher under Gramedia Group. Since then, more Japanese comics published on the next following years up to now. Japanese comics have different characteristics with the comics that had previously published in Indonesia, especially in terms of storytelling through pictures. Osamu Tezuka, the creator of Astro Boy, who is recognised as the father of modern Japanese Comic that emphasizing in time frame movement that gives "filmic" feeling to the readers, as perceived when watching film [9].

\section{EXPERIMENTAL DETAIL}

This research uses a qualitative research approach and implementing literature study approach on comic, specifically sequential art literature to obtain data as well as finding a theoretical framework to strengthen research results. Then, the data collections from researched objects are explained to describe the impact of the existence of Indonesian published comic to the society and Industry.

This paper will only discuss comics that are printed in the form of books that published in Indonesia, not supplements in newspapers or magazines, as it will also see how comics as a stand-alone medium.

\section{RESULTS AND DISCUSSION}

Comics in Indonesia have different characteristics in each period when they were published. By looking at the history of comics that published in Indonesia, they can be grouped based on the origin of those comics which are 1950 's to 1970 's as the era when Indonesian comics dominate the local market, 1970's to 1980's as the period of European-licensed comics flourished in Indonesia, and the early 1990's as the beginning of Japanese licensed Comic in Indonesia that survives up to now.

During the 1950's to 1970's, Indonesian comic artists have produced many comic genres such as fighting, Wayang, superhero, romance, and so on. In terms of graphic aesthetics, the illustration style has tried to depicting human characters in realistic anatomical proportions. The realistic visual approach on Indonesian comics that published on that period can be said that have got huge influenced from western comic strip in newspapers from that time. Indonesian comic artists try to convince their readers by displaying the anatomy and facial characteristics of Asian people, especially native Indonesian. This characteristic can be easily recognize through the anatomy of the body and face, such as the shape of the eyes, lips, and noses, in addition to presenting the settings, sometimes fictive but looks very Indonesian. This could be as an effort from the artist to make the reader closer to the characters. Even on the Wayang comics which there are many imaginative characters, the artists still describe it as closely as possible to the human form. It was clearly recognized from the attributes that visualized on the Wayang comics which taken from Wayang wong, classic live performance from central Java. In this case, the comic artists was trying to make classical wayang performance into the pop culture area, transformed them to other media that more attractive to the younger generations.

The European Licensed Comic that began to be published in Indonesia in the mid 1970's brought new insight to its readers about different approaches on graphic narrative. Some comics applying stylized cartoon approach, as well as setting and theme were totally different from local comics.

Most of European comic readers were generation who was born in the 70's in urban society, who may not have chance to know and interesting to read local comics. For them, the comics are considered more modern and classy because it often raises that days issues and actual events as a background story. Such as, racing cars world championship, the threat of terrorism, the adventure of French air force pilots, and so on, which visuallised on realistic detail both on the environment and human anathomic proportion. Some of them were also feels that the illustration style and the theme on Indonesian comics: defending the truth, the evil always defeated by goodness, were outdated.

The setback period for Indonesian comic in the 1970's might be due to not able to compete with the European comics in terms of providing the experience of reading, the diversity of full color illustration style, moreover theme and stories that consider with more international feels, aligned with the political and economic stability in Indonesia on that era, where the younger generation more open to accept new things from the outside.

Although European-Licensed Comic was responded positively by the Indonesian market, They were actually did not influenced the local comic artist, both on the story and visualisation style. Very different sutuation on the early era of Indonesian Comic in the 50's when the references were very limited and most of them from the comic strip on local newspapers that actually made local comic artist to produce more genres and dominate the market for more than 20 years.

Manga, the term for picture books or comics from Japan, with all its unique characteristics as a graphic narrative, It has become a graphic arts that accepted in many places in the world, including Indonesia. The first Manga that published in Indonesia in 1990 can be said as something that has been expected, after the animation film from Japan have already been recognized on urban society since 1980's. The comics are often portraying Japan in details in the package of simple fiction or non-fiction stories. The simple Japanese comic's visual style, such as human figures that are often visualized not in the actual anatomy proportion, expressive through exaggerated details, and easy to imitate, even not by a comic artists, makes it easily accepted by young readers.

The way of delivering the story through visuals on Manga is also very different from previous comics that 
ever published in Indonesia. The simple visual style, such as human figure which often visualized not in the actual anatomy proportion, expressive, and easily imitated not even by professional comic artists, makes it easily accepted by readers. Its unique visual narration that frequently dramatized, low-tempo sequences, makes the readers more flicking through, rather than reading so that more than 100 pages book can be completed briefly.

The presence of Japanese comics was also accused as the fall of local comics. However, it has re-emerged many new comic artists even though they are no longer visualizing Indonesian both on environment and design characters as it was during the 60-70s. On behalf of reviving original Indonesian comics and fulfilling the market taste, Indonesian comic artists have created Indonesian comics with Japanese flavor. Panji Tengkorak, originally created by Hans Jaladara in the 60's was once recreated in the manga format in 1996. The Garudayana Saga by Yuniarto, published in 2013, has also tried to introduce the story of Wayang to the younger generation on Japanese comic style. Regardless of the success or failure of the comic on the market, at least there is an attempt by young comic artists to review local content as the inspiration.

Other local comic artists had also tried to create a new Indonesian superhero, in order to revive Indonesian comic industry. Caroq, the new comic character created by Ahmad Thoriq and first published in 1996 with an illustration style that has been inspired by the American comic style as on the early of Indonesia superhero comic in the 50's. However, the existence of local comics that adopting the realistic approach illustration style from American superhero comics, they still cannot revive the local characters as in its heyday. It might be because the limited production number, or because the target audiences have already familiar with Japanese comics.

Looking at the market demand and the reader's interest in comics with the illustrations style from Japanese comic, the creative industry, especially comic studio and illustration, duplicate the way comics are published in Japan by publishing serial comics bundles as a media to introduce new comic artists before being published separately. The First bundle published by re: $O N$ in 2013, followed by Kosmik in 2015 as a media to introduce new comics that created Indonesian comic artists who often inspired Indonesian by story and setting. It's indicating that the presence of Japanese pop culture in Indonesia, in this case through comic, is well accepted by local market and industries, contributes to increase the growth of creative industry in Indonesia.

Apart from the originality issue, the presence of Indonesian comics with Japanese flavors are deserves to be recognized as part of the richness of Indonesia graphic arts and pop culture. Traced back to the comic that published from 1050's to 1970's that considered as the truly Indonesian comics, were actually influenced by comics from America. Only because applying illustration style in realistic approach that visualizing native Indonesian characteristic, furthermore, the theme and the story with local contents, makes them considered more original.

\section{CONCLUSIONS}

The appearance of local comics until their golden days in the 1960-1970s might be because of the political and economic stability in which made it possible to be published. The flourish of local comics is also due to the limited number of foreign licensed comic. At that time, foreign graphic narratives that can be found as comic strips on newspaper have become the inspiration for local comic artists.

In terms of graphic aesthetics, the illustration style has tried to depicting human characters in realistic anatomical proportions. The realistic visual approach on Indonesian comics that published on that period can be said that have got huge influenced from western comic strip in newspapers from that time. Indonesian comic artists try to convince their readers by displaying the anatomy and facial characteristics of Asian people, especially native Indonesian. This characteristic can be easily recognize through the anatomy of the body and face, such as the shape of the eyes, lips, and noses, in addition to presenting the settings, sometimes fictive but looks very Indonesian. This could be as an effort from the artist to make the reader closer to the characters.

In the 90's far from the heyday of Indonesian comic, young comic artists had also tried to create a new Indonesian superhero, in order to revive Indonesian comic industry and to match the popularity of American Superhero. As on the early of Indonesia superhero comic in the 50's, American comics once again have become the inspiration. However, the existence of local comics that adopting the realistic approach illustration style from American superhero comics still cannot revive the local graphic narrative as in its heyday. It might be because the limited production number, or because the target audiences have already familiar with Manga, the terminology for Japanese graphic narrative.

The simple Japanese comic's visual style, such as human figures that are often visualized not in the actual anatomy proportion, expressive through exaggerated details, and easy to imitate, even not by a comic artists, makes it easily accepted by young readers.

On behalf of reviving original Indonesian comics and fulfilling the market taste, Indonesian comic artists have created Indonesian comics with Japanese flavor. Apart from the originality issue, the presence of Indonesian comics with Japanese flavors are deserves to be recognized as part of the richness of Indonesia graphic arts and pop culture.

\section{ACKNOWLEDGMENT}

The authors would like to appreciate the Research and Technology Transfer Office and Bina Nusantara University for providing financial support for the research.

\section{REFERENCES}

[1] Hall, Andrew, Illustration, London, UK, Laurence King Publisher, 2011.

[2] Darmawan, Hikmat, How to Make Comic 2012

[3] Petersen Robert, Comics, Manga, and Graphic Novels: A History of Graphic Narratives, 2011

[4] McCloud Scott, Understanding Comic: The Invisible Art, 1993

[5] Boneff, Marcel, Komik Indonesia, 1998

[6] Boneff, Marcel, Komik Indonesia, 1998

[7] Boneff, Marcel, Komik Indonesia, 1998

[8] Petersen Robert, Comics, Manga, and Graphic Novels: A History of Graphic Narratives, 2011 